\title{
EDITORIAL
}

\section{Burnout among Medical Professions during Outbreaks}

\author{
Salar A. Khan, MD, MBA \\ Research Compliance Officer, Jesse Brown VA Medical Center, 820 S. Damen Avenue, Chicago, Illinois \\ Correspondence to: Email: salrub54@gmail.com, ORCiD: 0000-0002-9051-2442
}

The Corona Virus Disease-19 (COVID-19) outbreak spread globally on March 11, 2020 and the World Health Organization (WHO) declared this disease as a pandemic. This outbreak was sudden and spread all over the world. At the time of writing this article still COVID-19 cases are increasing among several countries. This disease has serious public health implications which not only increasing morbidity and mortality but has severe psychological trauma everyone is facing since the beginning of this outbreak. The COVID-19 vaccination started at the end of December 2019 in a few countries and now it is spread in several countries and the majority of people got their one or both shots hoping to get control on this outbreak soon and life will resume as usual. This outbreak created the atmosphere of uncertainty, fear, anxiety, and hopelessness throughout the whole world because millions of people including hundreds of physicians and paramedics around the globe were dead or still dying in various hospitals around the world. After vaccination people are getting confidence to move freely in the crowded places but still need more time to come out from COVID19 psychological trauma.

In this entire scenario, all physicians, medical and paramedical staff including nurses need great applause who worked 24/7 with very limited resources in several hospitals in third world countries trying to save the lives of others but some lose their own life in the process. Despite great progress and economic growth in the world; our world healthcare system was not ready to provide immediate services to the COVID-19 patients like enough oxygen, ventilators, and beds in the hospital. It was a total failure of the global leadership to work together but they started blaming each other which is not in favor of any of the countries, irrespective of their status. At this point, it seems that the world leader has not learned a lesson through this pandemic or again, and they might wait for another pandemic crisis to come and kill all of us. Furthermore, still no combined strategy is set up by the authorities to effectively manage the pandemic. In the past, outbreaks like the influenza (flu) pandemic of 1918-1919 killed between 20 and 40 million peoples. In 2009, influenza $A$ virus subtype $\left(\mathrm{H}_{1} \mathrm{~N} 1\right)$ was a more recent global pandemic. One thing that needs more focus during this pandemic is COVID-19 outbreaks and its impact on mental health of healthcare professionals including physicians. ${ }^{1}$

Burnout is a genuine issue that can lead to devastating personal and professional consequences. ${ }^{2,3}$ During COVID-19 pandemic, physicians with burnout cannot provide quality care to patients, and it increases the chance of medical errors, poor decision making, hostile attitudes toward patients, and difficult relationships with coworkers. ${ }^{4,5}$ Physicians belong to a highly vulnerable group for experiencing burnout in this pandemic. Several factors like increased risk of anxiety and depression, poor sleep, increased workload, misuse of drugs, and difficult marital relationships were noticed as a global issue among physicians in several countries. To cope up this difficult situation, the general workplace population, and particularly physicians, must show flexibility or quick adaptability to overcome stress. Employers must try to provide a healthy, stressfree work environment so that employees can achieve work-life balance and enjoy job security while preventing burnout. ${ }^{6,7}$ Once the burnout process has started, then a psychological consultation is needed to begin cognitive behavioral therapy and learn relaxation techniques. At the same time, cooperation is required from employers to improve the work environment. Prevention is always better than treatment when it comes to burnout. The extent of burnout may vary depending on the practice setting, specialty, and changing work environment. An understanding of dynamic risk factors associated with burnout may help to prevent and treat burnout. Physicians can recover from burnout because they are professional and understand their own psychology, allowing for a quick recovery from precipitating stressful situations. There is no need to quit or change jobs or to think about early retirement if you are self-motivated to accept burnout 
Khan. Burnout among Medical Professions during Outbreaks

Supervisor or Manager's Early Assessment of Employee Burnout

\begin{tabular}{|c|c|c|c|c|c|c|}
\hline Supervisor or Manager's Assessment & $\begin{array}{l}\text { Strongly } \\
\text { Disagree }\end{array}$ & Disagree & Neutral & Agree & $\begin{array}{l}\text { Strongly } \\
\text { Agree }\end{array}$ & Response \\
\hline $\begin{array}{c}\text { Employee's inability to manage day-to- } \\
\text { day activities }\end{array}$ & 1 & 2 & 3 & 4 & 5 & \\
\hline Employee looks under pressure at work & 1 & 2 & 3 & 4 & 5 & \\
\hline $\begin{array}{c}\text { Employee is taking long time to } \\
\text { complete task }\end{array}$ & 1 & 2 & 3 & 4 & 5 & \\
\hline Employee struggles to meet deadlines & 1 & 2 & 3 & 4 & 5 & \\
\hline $\begin{array}{l}\text { Employee is unable to meet high job } \\
\text { demands due to poor control }\end{array}$ & 1 & 2 & 3 & 4 & 5 & \\
\hline $\begin{array}{l}\text { There are high expectations at work, } \\
\text { and the employee is unable to meet the } \\
\text { constant demands at work }\end{array}$ & 1 & 2 & 3 & 4 & 5 & \\
\hline $\begin{array}{l}\text { Employee is missing deadlines due to } \\
\text { forgetfulness }\end{array}$ & 1 & 2 & 3 & 4 & 5 & \\
\hline Employee has a mismatch of job skill set & 1 & 2 & 3 & 4 & 5 & \\
\hline $\begin{array}{c}\text { Employee has a lack of enthusiasm and } \\
\text { motivation }\end{array}$ & 1 & 2 & 3 & 4 & 5 & \\
\hline $\begin{array}{l}\text { Employee productivity at work is } \\
\text { decreasing }\end{array}$ & 1 & 2 & 3 & 4 & 5 & \\
\hline Employee regularly calls in sick & 1 & 2 & 3 & 4 & 5 & \\
\hline Employee interest at work is decreasing & 1 & 2 & 3 & 4 & 5 & \\
\hline Employee shows irritability & 1 & 2 & 3 & 4 & 5 & \\
\hline Employee hates his or her job & 1 & 2 & 3 & 4 & 5 & \\
\hline $\begin{array}{l}\text { Employee does not care about work } \\
\text { while at the job }\end{array}$ & 1 & 2 & 3 & 4 & 5 & \\
\hline
\end{tabular}

Scoring: $<30=$ Not burned out; $30-60=$ would welcome a few changes at work; $>60=$ Early phases of burnout, needing corrective action to prevent late onset of burnout.

as a challenge: you know how you can overcome it, or you can seek advice from a psychologist or psychiatrist. Physicians in many countries are experiencing great frustration in practicing medicine particularly during COVID-19 pandemic due to limited resources and corporate micromanagement of health-care delivery, media reports of medical errors, and unethical physician conduct. Patients challenge physicians' authority and skills. Patients also challenge other health-care-related providers, such as insurance companies.

When burnout manifests, it typically begins with a general feeling of exhaustion and then progresses through a series of increasingly severe phases, including depression, insomnia, and substance abuse. At the end of this decline, the ultimate result is a worker with serious physical and psychological ailments who is 54 no longer able to perform their duties at all. Self-care involves remaining watchful for signs of burnout and trying to maintain a positive attitude, as well as surrounding oneself with like-minded colleagues. If these conditions prove to be elusive, then it may be time to seek employment elsewhere - either a new workplace or perhaps an entirely different type of work. For those in managerial positions, instituting healthy time management and conflict resolution practices can reduce stress, and programs can be instituted to educate employees and help them to deal with the pressures of their work. Overall, it is simply important for workers, managers, and doctors to recognize that burnout is a real psychological condition and take the appropriate steps to prevent and treat it. ${ }^{8}$ Burnout is dysfunctional state not diagnosed by labs or $\mathrm{x}$-rays, but it has a real effect on physician's lives. 
Khan. Burnout among Medical Professions during Outbreaks

One way to overcome the COVID-19 pandemic physician burnout at the organizational level is to create an "Employee Burnout Assessment Questionnaire" as above to use as an early assessment tool. We all must be ready as a healthcare professional to deal with any other future pandemic efficiently and effectively in order to learn a lesson with the current pandemic to handle such situations in a much better way. ${ }^{9}$

Burnout and stress management topics should be included in college and university curricula targeting medical students, residents, and practicing physicians to improve psychological well-being, professional career enjoyment, and the quality of care provided to patients.

\section{REFERENCES}

1. World Health Organization .Health impact of psychosocial hazards at work: An overview [Internet]. 2018. Available from: http://www.who.int/occupational health/publications/hazardpsychosocial/en

2. Diagnosing Burnout - Not as Easy as You Might Think [Internet]. 2016. Available from: http://www.pauldec hantmd.com/diagnosing-burnout/

3. Miller RN. Measure, act on these 6 factors tied to physician burnout.[Internet]. 2017. Available from: https://wire.ama-assn.org/life-career/measure-actthese -6-factors-tied-physician-burnout.

4. Myers IB, Meyers PB. Gifts differing: understanding personality type. Palo Alto, California: Davies-Black Publishing: 1995 .

5. Jung CG, Collected Works of C. G. Jung, Volume 6: Psychological Types. Princeton University Press; 1971.

6. Maslach C, Leiter MP. Understanding the burnout experience: recent research and its implications for psychiatry. World Psychiatry 2016; 15:103-11. doi: $10.1002 /$ wps.20311

7. Freudenberger HJ. Staff Burn-Out. J Social Issue 1974; 30:159-65. doi:10.1111/j.1540-4560.1974.tboo706.x

8. Shanafelt TD, Hasan O, Dyrbye LN, Sinsky C, Satele D, Sloan J, et al. Changes in Burnout and Satisfaction With Work-Life Balance in Physicians and the General US Working Population Between 2011 and 2014. Mayo Clin Proc 2015; 90:1600-13. doi: 10.1016/j.mayocp.2015.08.023

9. Khan SA. Am I Burned Out at Work? A Self-Care Solution. Bloomington, IN: Archway Publishing 2019; 32-59. 